\title{
Effects of body condition score and daily milk yield on reproduction traits of Czech Fleckvieh cows
}

\author{
Ludek Stadnik ${ }^{1}$, Savas Atasever $^{2,3}$, Jaromir Ducháček ${ }^{1}$ \\ ${ }^{1}$ Czech University of Life Sciences Prague, Faculty of Agrobiology, Food and Natural Resources, Department Animal \\ Husbandry, Kamýcká 129, 165 21, Prague 6 - Suchdol, Czech Republic. \\ ${ }^{2}$ Ondokuz Mayis University, Faculty of Agriculture, Departament Animal Science, 55139, Samsun, Turkey.
}

\begin{abstract}
The objective of this study was to evaluate the effects of body condition score (BCS) and daily milk yield (DMY) on reproductive characteristics of dairy cows. A total of 1249 records of Czech Fleckvieh cows raised at a private farm in Prague were enrolled. Dairy cows were grouped according to BCS $(1=\leq 3.75,2=4-4.25$ and $3=\geq 4.50)$ and DMY groups $(<20 \mathrm{~kg}, 20-30 \mathrm{~kg}$ and $>30 \mathrm{~kg})$. Number of inseminations per pregnancy (NI), days open (DO), service period (SP) and ovarian cyst (OC) cases were evaluated as reproduction characteristics. While the group with $\mathrm{BCS} \geq 4.50$ presented higher $\mathrm{DO}$, the group with $\mathrm{BCS} \leq 3.75$ had lower OC cases when compared with other BCS groups. The group with $\mathrm{DMY}<20 \mathrm{~kg}$ had higher DO but lower OC cases than other DMY groups. Significant correlations were estimated between SP and NI $(r=0.843)$ or DO $(r=0.256)$, and between $\mathrm{OC}$ and DO $(\mathrm{r}=0.546)$. The results revealed the effects of BCS and DMY on DO and OC and associations of reproduction traits each other. Therefore, close tracking production and reproduction data is suggested as a major process to prevent fertility problems and to obtain high productivity in dairy cows.
\end{abstract}

Keywords: correlation, dairy cow, days open, milk yield, ovarian cyst.

\section{Introduction}

Reproduction disorders cause huge problems in dairy cattle herds. In this respect, realizing biochemical and physiological precepts, monitoring fertility and lactation may be seen as a logical approach to elevate reproductive performance of milking cows (Thatcher et al., 2006). The reason of low fertility in dairy herd is multifactorial (Roche, 2006), and genetics, environment, herd management and nutrition may be assumed the principal factors affecting fertility (Beever, 2006). To manage a high fertile herd, keeping production records truly and meticulously observing estrus has a great value. In an elite herd, reproduction traits should be existed in the optimum thresholds, because higher means of these parameters reflect fertility problems in dairy herds. Fertility rate of a dairy herd is expected to decline with high number of inseminations per pregnancy (NI) per successful conception, prolonged calving intervals and increment in culling because of failure to rebreed, all integrating marked outcomes to milk yield (Beever, 2006). Jeengar et al. (2014) indicated that presence of ovarian cysts (OC) causes for a reduction in conception rate and prolonged calving intervals. Detecting OC in an early time is suggested due to late cyst about 36 times greater than early cyst (Lopez-Gatius et al., 2002). Roche (2006) emphasized that cows with OC take longer to days open (days from calving to the first insemination; DO) and service period (days from calving to subsequent pregnancy; SP).

In spite of dairy sector principally focused on achieving the high amount milk (Cziszter et al., 2017), dairy cows selected according to higher milk production may expose to less reproductive performance. Kafi and Mirzaei (2010) informed that, in addition to high milk yield, some environmental factors, for instance calving disorders, improper post-partum feeding regime or heat stress contribute to poor reproductive performance of dairy cows. Gröhn and Rajala-Schultz (2000) emphasized that cows with higher milk yield were more experienced in $\mathrm{OC}$ cases than cows with relatively lower milk yield. Also, Stadnik et al. (2017) point out that reproduction and milk yield traits had negative correlations throughout lactation. Loker et al. (2009) reported prolonged DO in cows with relatively higher milk yield. Similarly, Heuer et al. (1999) emphasized that higher first test day milk yield indirectly dropped fertility performance of dairy cows. It was informed that cows with lower milk production had 1.09 to 1.38 likelihood for pregnancy than cows with higher milk yield (Piccardi et al., 2013). Therefore, in addition to reproduction traits, milk yield has certainly been advised to regard as an important parameter for selection of breeding cows in dairy herds (Puangdee et al., 2017).

Instead of direct reproductive characters, some indirect parameters may contribute an important value to the profitability of dairy cows. Body condition score (BCS) is commonly used throughout the world to detect fatness or muscular status of a cow. Actually, the nutritional conditions of dairy cows have significantly related to production diseases or animal welfare (Mulligan et al., 2006). Wathes et al. (2003) informed that dairy cows with weak energy status have less insulin-like growth factor 1 (IGF-1) circulation. Divergence in normal BCS levels clearly point out to managemental failures in the herds. Dairy cows with a high BCS loss may likely candidate to OC cases when compared to cows with low BCS loss (Gossen et al., 2006). To minimize BCS losses, keeping cows in 2.753.0 BCS at calving has been suggested (Roche, 2006). However, high BCS should also be seen as a risk factor for poor fertility and reproduction disorders in lactating cows. Lopez-Gatius et al. (2002) reported that a 1-unit 
BCS elevation from pre-partum $60 \mathrm{~d}$ to calving raised the $\mathrm{OC}$ risk 8.4 times. On the other hand, Ruegg and Milton (1995) found no relationship between BCS loss and DO. Many studies have indicated the factors affecting fertility characteristics in dairy cows (Thatcher et al., 2006; Tanaka et al., 2008; Cavestany et al., 2009; Hartmann et al., 2016). To the best of our knowledge, there is no detailed information on the effects of BCS and milk yield on reproductive traits in Fleckvieh cows. Revealing these effects may be expected to enhance fertility ability of cows, and to ensure important economic input for dairy enterprises. Therefore, the aim of the present investigation was to evaluate the effects of BCS and DMY on the reproduction characteristics of Czech Fleckvieh cows.

\section{Material and Methods}

Cow Selection

This study was conducted in a private farm in Praque, Czech Republic. A total of 1249 records of Czech Fleckvieh cows those in early lactation period (min:5d, max:39d) between 2009 and 2010 were assessed by BCS, daily milk yield (DMY) and some reproduction traits. The cows were milked twice in a day with automatic machine and kept in similar conditions throughout the experiment. While the average milk yield per lactating cow was $27.56 \pm 0.18 \mathrm{~kg}$, all cows were loose housed in a cubicle straw-bedded barn and fed a total mixed ration (TMR). The contents of the ration matched to the presented daily milk yield of individual cows, and diets were definitively balanced for energy, protein, fat, minerals and vitamins. Diets comprised of the same components and water was available ad libitum during the overall investigation process.

\section{Body Condition Scoring}

Body conditions of the cows were scored by the only one technician using a 1-5-point scale (Stadnik and Atasever, 2015). Emaciated cow were scored 1; thin cows 2; average cows 3; fat cows 4 and obese cows 5 . Scoring was performed with 0.25 or 0.50 units if it needed (e.g., 2.75 or 3.50) and the scorer did not have regard to the initial points during the next scoring.

\section{Reproduction Traits}

To assess the effect of BCS and DMY on the reproduction characteristics; NI, DO, SP and OC were selected as reproduction parameters. The diagnosis of ovarian cysts cases was made by a veterinarian, according to customary clinical methods under normal field conditions using an ultrasound scanner, Tringa Linear (Canmedical, Ontario, Canada). Data were collected from the herd personnel records or the herd veterinarian's farm treatment records.

\section{Statistical Analysis}

For the evaluation of both selected factors with parity, five groups were designed (parity 1, 2, 3, 4 and $\geq 5$ ). To assess the effect of BCS, three groups were designed for $(\leq 3.75 ; 4$ to 4.25 ; and $\geq 4.50)$. For evaluating DMY based on the reproduction characteristics; cows were tested in three groups $(<20 \mathrm{~kg} ; 20$ to $30 \mathrm{~kg}$; and $>30 \mathrm{~kg})$.

To determine the effects environmental factors, analysis of variance were performed and the means were compared by Tukey test $(\mathrm{P}<0.05)$. The linear model was: $\mathrm{Y}_{i j k l}=\mu+\alpha_{i}+\beta_{j}+\gamma_{k}+e_{i i j k l} \quad$ where, $\mathrm{Y}_{i j k l}$ is the observation value, $\mu$ is the overall mean, $\alpha_{i}$ is effect of parity on BCS and DMY, $\beta_{j}$ is effect of $\mathrm{BCS}$ on reproduction traits, $\gamma_{k}$ is effect of DMY on reproduction traits, and $e_{i j k l}$ is random error.

To determine the associations of the markers to each other, Pearson's correlation coefficients were estimated. In this stage, the changed levels of BCS (CBCS) from calving date to test day were used for statistical work. All statistical analyses were performed by SPSS 17.0 for Windows at the 0.05 significance level.

\section{Results}

In this study, variations in BCS and DMY according to parity are presented in Table 1 . As seen that the lowest BCS mean was obtained from the first parity group and the highest was obtained from the 3rd and 5th parities. DMY was calculated to be the lowest in the cows with the first parity and it was the highest in those with 2 nd and 3 rd parities. In other words, DMY increased by $30.92 \%$ and $29.74 \%$ in cows with 2 nd and $3 \mathrm{rd}$ parities, and then decreased by $6.34 \%$ and $5.84 \%$ in cows with 4th and 5th parities, respectively.

Table 2 shows that NI was relatively higher in the first BCS group up to $27.62 \%$ and $33.14 \%$ when compared to other groups, but no significant effect of BCS on NI was found. While the highest NI mean was determined from the first DMY group, no significant effect of DMY on NI was found as similar to BCS evaluation. This result points out that both BCS and DMY were not effective factors for NI.

However, DO was significantly $(\mathrm{P}<0.05)$ affected by BCS and DMY. It can be seen that DO of the third BCS group was significantly $(\mathrm{P}<0.05)$ higher than other groups. In contrast to this finding, DO decreased with advanced DMY levels. Actually, cows with $<20 \mathrm{~kg}$ DMY had longer DO in the current study. However, no significant effects of BCS and DMY on SP were determined in the present study and, in other words, the effects of both environmental factors on SP were equal in all groups similar to NI. Besides, a high number of cows $(\sim 53 \%)$ had OC in our study (Table 2$)$. Also, cows with lower BCS and DMY had lower OC (P $<0.05)$ when compared to other groups.

In this study, relatively high $(\mathrm{P}<0.01)$ correlation coefficient was estimated between NI and SP $(\mathrm{r}=0.843)$. Besides, DO was significantly correlated with SP $(r=0.256 ; \mathrm{P}<0.05)$ and OC $(r=0.546 ; \mathrm{P}<0.01)$. However, non-significant positive or negative correlation coefficients were calculated among the other characters. 


\section{Discussion}

Normally, change of BCS among the parities is an expected result. However, Stadnik et al. (2002) and Meikle et al. (2004) emphasized that primiparous cows had relatively lower BCS when compared to cows with advanced parities. Actually, the first parity cows are exposed to uncompleted endocrinal and metabolic activity in that time. However, drastic body weight losses would be expected, especially for multi-parity cows in relation to their higher milk yield. In this context, our finding here (Table 1) is parallel to results of some researchers (Ezanno et al., 2003; Sakaguchi, 2009). Besides, calculated mean of BCS of the present study was found as similar to that calculated by Duchacek et al. (2012) for Czech Fleckvieh cows and it could be assumed in the suitable thresholds for dairy cows of this dual purpose breed.

Table 1 . BCS and DMY means $( \pm S E)$ by parity groups.

\begin{tabular}{lcccc}
\hline Parity & $\mathrm{n}$ & $\mathrm{BCS}$ & $\mathrm{n}$ & DMY \\
\hline 1 & 319 & $3.98 \pm 0.02^{\mathrm{c}}$ & 308 & $22.83 \pm 0.23^{\mathrm{c}}$ \\
2 & 386 & $4.14 \pm 0.02^{\mathrm{b}}$ & 365 & $29.89 \pm 0.27^{\mathrm{b}}$ \\
3 & 282 & $4.35 \pm 0.02^{\mathrm{a}}$ & 264 & $29.62 \pm 0.37^{\mathrm{b}}$ \\
4 & 119 & $4.15 \pm 0.04^{\mathrm{b}}$ & 115 & $27.74 \pm 0.77^{\mathrm{a}}$ \\
5 & 143 & $4.30 \pm 0.03^{\mathrm{a}}$ & 137 & $27.89 \pm 0.58^{\mathrm{a}}$ \\
\hline Total & 1249 & $4.17 \pm 0.01$ & 1189 & $27.56 \pm 0.18$ \\
\hline
\end{tabular}

Different superscript letters in the same column indicate statistically significant differences $(\mathrm{P}<0.05), \mathrm{BCS}$ : body condition score (point); DMY: daily milk yield (kg).

Obtained lowest DMY in the cows with the first parity of this study indicates that primiparous Czech Fleckvieh cows produced relatively low milk as a result of younger age and also their inexperience for lactation. Bayou et al. (2015) emphasized that a dairy cow can present more potential milk production in terms of the matured mammary gland with higher parity. A general concept that the first parity cows are intensely exposed to negative energy balance and this case may cause to a drastic reduction in milk yield. Besides, determined the DMY mean per cow could be assumed in normal thresholds for dairy cows. The results obtained here were found to be harmonic with BCS values calculated in parity base.

In the current study, calculated general NI mean might be assumed to be moderate and not so effective for dual purpose dairy cows as generally expected. The mean of the study was found to be lower than that determined by Aeberhard et al (2001) and Ansari-Lari et al. (2010). The different breeds of the studies might be regarded to be the main reason for this finding. Similar NI means in Fleckvieh breed that calculated by Duchacek et al (2012) and Cziszter et al. (2017) supports this case. Chebel et al. (2004) reported that non-genetic factors affect NI and reproductive efficiency. In this context, readjustments on herd management and especially on estrus observation, respectively estrus synchronization should exactly be performed to achieve more productivity.

As known, DO is routinely used to evaluate fertility performance and to calculate economic decision in dairy cows (Bahonar et al., 2009; Stadnik et al., 2015). The findings of this study indicate that elevated BCS affected negatively to DO in Czech Fleckvieh cows. Conversely, $10.6 \mathrm{~d}$ longer DO in cows with severe BCS loss (drop in $\mathrm{BCS}>1$ ) during the early period of lactation was reported (Lopez-Gatius et al., 2003). Therefore, keeping cows in moderate BCS can be advised to cattle breeders to avoid the adverse effects of mobilization of body tissues or depositing fat. On the other hand, shortened DO with higher DMY of our study might be assumed as a favorable result. Really, calculated highest DO in cows with lower DMY might be associated with a marginal milk production capacity of the cow's body. Sangsritavong et al. (2002) emphasized that cows with higher milk yield exposed to complications in natural luteolytic cycle due to raised steroid but decreased estradiol concentrates through high feed intake. Nevertheless, Aeberhard et al. (2001) indicate that influence of high milk yield with reproduction characters is largely phenotypic due to low heritability of reproduction traits. Also, Ansari-Lari et al. (2010) point out that the fertility failures due to high DMY occurred only in inadequate feeding conditions or environment. Moreover, Kaewlamun et al. (2011) emphasized in their study that extended DO may be associated with insufficient diets during dry period. Therefore, focusing non-genetic factors, especially on managemental factors may be seen a positive approach to boost reproductive efficiency in the dairy farms. However, the results here were interpreted as contradictive with the findings of Ansari-Lari et al. (2010), who found negative effects of higher DMY on DO and SP. Also, Piccardi et al. (2013) reported a linear elevation of DO with advancing milk yield. These disagreements might be caused by animal number, management, region or breed differences between this study and mentioned investigations. Moreover, the current study has only focused on the early stage of lactation.

Normally, a positive association could be expected between DO and SP, and length of these periods may cause decreased milk production and culling in dairy herds. In spite of similar SP from Czech Fleckvieh cows was also reported by Duchacek et al. (2012), calculated mean for SP here could be assumed as relatively long for a dual purpose breed in relation to milk yield level (Cilek and Tekin, 2005; Ulutas and Sezer, 2009; Sawa and Bogucki, 2011). This case clearly points out a management problem in the evaluated herd. As a general statement, OC cases are frequently exposed by high producing dairy cows (Yániz et al., 2008) and adversely affects fertility of cows (Bahonar et al., 2009). Normally, excessive BCS is highly related to OC cases (Zulu et al., 2002) and as a harmonic result, $\mathrm{BCS}$ significantly $(\mathrm{P}<0.05)$ affected $\mathrm{OC}$ in Fleckvieh cows (Table 2). Especially overconditioning may be referred to weak fertility or nutrition programs in dairy farms. That's why; preventing cows from high BCS should principally be considered to obtain fertile cows. 
Stadnik et al. Factors affecting cow fertility.

Table 2. Means $( \pm \mathrm{SE})$ of reproduction traits by BCS and DMY groups.

\begin{tabular}{lcccccccc}
\hline BCS & $\mathrm{n}$ & NI & $\mathrm{n}$ & $\mathrm{DO}$ & $\mathrm{n}$ & $\mathrm{SP}$ & $\mathrm{n}$ & OC \\
\hline $1(\leq 3.75)$ & 255 & $1.81 \pm 0.06$ & 270 & $70.82 \pm 0.99^{\mathrm{b}}$ & 255 & $104.84 \pm 2.89$ & 79 & $8.98^{\mathrm{b}}$ \\
$2(4-4.25)$ & 459 & $1.76 \pm 0.05$ & 475 & $70.86 \pm 0.42^{\mathrm{b}}$ & 459 & $100.53 \pm 1.89$ & 201 & $22.86^{\mathrm{a}}$ \\
$3(\geq 4.50)$ & 388 & $1.75 \pm 0.06$ & 410 & $73.04 \pm 0.64^{\mathrm{a}}$ & 388 & $100.23 \pm 2.48$ & 189 & $21.50^{\mathrm{a}}$ \\
\hline Total & 1102 & $1.77 \pm 0.03$ & 1155 & $71.62 \pm 0.37$ & 1102 & $101.42 \pm 1.35$ & 469 & 53.35 \\
\hline DMY & & & & & & & & \\
\hline $1(<20 \mathrm{~kg})$ & 83 & $1.76 \pm 0.09$ & 93 & $76.05 \pm 2.30^{\mathrm{a}}$ & 83 & $104.75 \pm 4.76$ & 30 & $3.69^{\mathrm{b}}$ \\
$2(20-30 \mathrm{~kg})$ & 532 & $1.77 \pm 0.04$ & 559 & $70.62 \pm 0.48^{\mathrm{b}}$ & 532 & $100.29 \pm 1.90$ & 221 & $27.11^{\mathrm{a}}$ \\
$3(>30 \mathrm{~kg})$ & 424 & $1.75 \pm 0.05$ & 439 & $71.82 \pm 0.48^{\mathrm{b}}$ & 424 & $102.05 \pm 2.23$ & 184 & $22.57^{\mathrm{a}}$ \\
\hline Total & 1039 & $1.76 \pm 0.03$ & 1091 & $71.56 \pm 0.37$ & 1039 & $101.37 \pm 1.38$ & 435 & 53.37 \\
\hline
\end{tabular}

Different superscript letters in the same column indicate statistically significant differences $(\mathrm{P}<0.05)$. BCS: body condition score; DMY: daily milk yield (kg) NI: number of inseminations per pregnancy; DO: days open (d); SP: service period $(\mathrm{d})$; OC: ovarian cyst $(\%)$.

In this study, elevated OC percentage with advancing DMY were found as harmonic with findings from Vacek et al. (2007) and it can be explained by the normal physiologic mechanism of dairy cow to produce more milk (Hooijer et al., 2001). Really, the lowest OC cases of cows in the lowest BCS and DMY groups might be connected with the lower physiologic stress of those cows when compared to the others. To boost the activity of oocytes, adding $\beta$-carotene to the diets was suggested by De Bie et al. (2016). Interestingly, calculated OC percentage of cows with DMY $<20 \mathrm{~kg}$ was found as similar to that estimated by Eicker et al. (1996) in New York Holstein cows. Braw-Tal et al. (2009) reported that development of OC is related to an endocrinal imbalance and this mechanism is still not fully understood. Thus, effective factors on the occurrence of OC should individually be examined in the further investigations.

Estimated correlations here (Table 3) can be assumed as an expected case. Really, higher NI might be caused to increase for SP (Cilek and Tekin, 2005; Akilli et al., 2016). Besides, the findings here disagreed with the results of Heuer et al. (1999). Differences in breed, nutrition or husbandry practices of the investigations might be seen the possible reason of this conflict. However, revealed correlation coefficient between NI and SP (0.84) clearly points out that the chance for conceive after insemination was quite low in the investigated Fleckvieh herd and found to be similar range (0.81) with that determined by Cilek and Tekin (2005). At this point, rechecking fertility plans, especially on NI and DO should be advised to the dairy breeders to manage more reproductive cows.

Table 3. Correlation coefficients among investigated characters.

\begin{tabular}{lccccc}
\hline Trait & DO & SP & OC & CBCS & DMY \\
\hline NI & -0.059 & $0.843^{* *}$ & -0.080 & 0.006 & 0.005 \\
DO & & $0.256^{*}$ & $0.546^{* *}$ & 0.016 & -0.008 \\
SP & & & 0.036 & 0.011 & 0.014 \\
OC & & & -0.015 & 0.019 \\
CBCS & & & & -0.046 \\
\hline *P < 0.05, **P < 0.01; DO: days open; SP: service period; \\
OC: ovarian cyst; CBCS: change in BCS, DMY: daily milk \\
yield; NI: number of inseminations per pregnancy.
\end{tabular}

Finally, the present study clearly revealed that both BCS and DMY significantly $(\mathrm{P}<0.05)$ influenced DO and OC, which are assumed to be important reproduction traits in dairy cows. Moreover, significant $(\mathrm{P}<0.05$ or $\mathrm{P}<0.01)$ associations were detected among the evaluated reproduction traits. Therefore, paying more regard to production and reproduction records should be seen to be a major process to prevent fertility problems and to obtain high yielding cows in dairy herds.

\section{Acknowledgements}

Authors acknowledge directorate of the farm for valuable assistance in data ensuring.

\section{References}

Aeberhard K, Bruckmaier RM, Kuepper U, Blum JW. 2001. Milk yield and composition, nutrition, body conformation traits, body condition scores, fertility and diseases in high-yielding dairy cows-Part 1. J Vet Med A, 48:97-110.

Akilli A, Atil H, Takma C, Ayyilmaz T. 2016. Fuzzy logic-based decision support system for dairy cattle. Kafkas Univ Vet Fak Derg. 22(1):13-19.

Ansari-Lari M, Kafi M, Sokhtanlo M, Ahmadi HN. 2010. Reproductive performance of Holstein dairy cows in Iran. Trop Anim Health Prod, 42:1277-1283.

Bahonar AR, Azizzadeh M, Stevenson MA, Voigani M, Mahmoudi M. 2009. Factors affecting days open in Holstein dairy cattle in Khorasan Razavi Province, Iran; A cox proportional hazard model. J Anim Vet $A d v$, 8:747-754.

Bayou E, Haile A, Gizaw S, Mekasha Y. 2015. Evaluation of non-genetic factors affecting calf growth, reproductive performance and milk yield of traditionally managed Sheko cattle in southwest Ethiopia. Springerplus. 4:568.

Beever DE. 2006. The impact of controlled nutrition during the dry period on dairy cow health, fertility and performance. Anim Reprod Sci, 96:212-226.

Braw-Tal R, Pen S, Roth Z. 2009. Ovarian cysts in high-yielding dairy cows. Theriogenology. 72:690-698.

Cavestany D, Viñoles C, Crowe MA, La Manna A, Mendoza A. 2009. Effect of prepartum diet on postpartum ovarian activity in Holstein cows in a pasture-based dairy system. Anim Reprod Sci, 114:1-13. 
Chebel RC, Santos JEP, Reynolds JP, Cerri RLA, Juchem SO, Overton M. 2004. Factors affecting conception rate after artificial insemination and pregnancy loss in lactating dairy cows. Anim Rep Sci, 84:239-255.

Cilek S, Tekin ME. 2005. Environmental factors affecting milk yield and fertility traits of Simmental cows raised at the Kazova State Farm and phenotypic correlations between these traits. Turk J Vet Anim Sci, 29:987-993.

Cziszter LT, Ilie DE, Neamt RI, Neciu FC, Saplacan SI, Gavojdian D. 2017. Comparative study on production, reproduction and functional traits between Flechvieh and Braunvieh cattle. Asian-Australas J Anim Sci, 30:666-671.

De Bie J, Langbeen A, Verlaet AAJ, Florizoone F, Immig I, Hermans N, Fransen E, Bols PEJ, Leroy JLMR. 2016. The effect of a negative energy balance status on -carotene availability in serum and follicular fluid of nonlactating dairy cows. J Dairy Sci, 99:58085819.

Duchacek J, Vacek M, Stadnik L, Beran J, Vodkova Z, Rohlikova V, Nejdlova M. 2012. Relationship between energy status and fertility in Czech Fleckvieh cows. Acta Univ Agric et Silvic Mendel Brun, 60(6):6774.

Eicker SW, Gröhn YT, Hertl JA. 1996. The association between cumulative milk yield, days open, and days to first breeding in New York Holstein cows. $J$ Dairy Sci, 79:235-241.

Ezanno P, Ickowicz A, Bocquier F. 2003. Factors affecting the body condition score of N'Dama cows under extensive range management in Southern Senegal. Anim Res, 52:37-48.

Gossen N, Fietze S, Mösenfechtel S, Hoedemaker M. 2006. Relationship between body condition (back fat thichness and body condition scoring) and fertility in dairy cows (German Black Pied/HF). Dtsch Tierarztl Wochenschr, 113:171-172, 174-177.

Gröhn YT, Rajala-Schultz PJ. 2000. Epidomiology of reproductive performance in dairy cows. Anim Rep Sci, 60-61:605-614.

Hartmann D, Rohkohl J, Merbach S, Heilkenbrinker T, Klindworth HP, Schoon HA, Hoedemaker M. 2016. Prevalence of cervicitis in dairy cows and its effect on reproduction. Theriogenology, 85:247-253.

Heuer C, Schukken YH, Dobbelaar P. 1999 Postpartum body condition score and results from the first test day milk yield as predictors of disease, fertility, yield, and culling in commercial dairy herds. J Dairy Sci, 82: 295-304.

Hooijer GA, Lubbers RBF, Ducro BJ, van Arendonk JAM. 2001. Genetic parameters for cystic ovarian disease in Dutch Black and White cattle. J Dairy Sci, 84:286-291.

Jeengar K, Chaudhary V, Kumar A, Raiya S, Gaur M, Purohit GN. 2014. Ovarian cysts in dairy cows: old and new concepts for definition, diagnosis and therapy. Anim Reprod, 11:63-73.

Kaewlamun W, Chayaratanasin R, Virakul P, Ponter AA, Humblot P, Suadsong S, Tummaruk P, Techakumphu M. 2011. Differences of periods calving on days open of dairy cows in different regions and moths of Thailand. Thai J Vet Med, 41:315-320.

Kafi M, Mirzai A. 2010. Effects of first postpartum progesterone rise, metabolites, milk yield, and body condition score on the subsequent ovarian activity and fertility in lactating Holstein cows. Trop Anim Health Prod, 42:761-767.

Loker S, Miglior F, Bohmanova J, Jamrozik J, Schaffer LR. 2009. Phenotypic analysis of pregnancy effect on milk, fat, and protein yields of Canadian Ayrshire, Jersey, Brown Swiss, and Guernsey breeds. $J$ Dairy Sci, 92:1300-1312.

Lopez-Gatius F, Santolaria P, Yaniz J, Fenech M, Lopez-Bejar M. 2002. Risk factors for postpartum ovarian cysts and their spontaneous recovery or persistence in lactating dairy cows. Theriogenology, 58:1623-1632.

Lopez-Gatius F, Yaniz J, Madriles-Helm D. 2003. Effects of body condition score and score change on the reproductive performance of dairy cows: a metaanalysis. Theriogenology, 59:801-812.

Meikle A, Kulcsar M, Chilliard Y, Febel H, Delavaud C, Cavestany D, Chilibroste P. 2004. Effects of parity and body condition at parturition on endocrine and reproductive parameters of the cow. Reproduction, 127:727-737.

Mulligan FJ, O'Grady L, Rice DA, Doherty ML. 2006. A herd health approach to dairy cow nutrition and production diseases of the transition cow. Anim Reprod Sci, 96:331-353.

Piccardi M, Capitaine Funes A, Balzarini M, Bó GA. 2013. Some factors affecting the number of days open in Argentinean dairy herds. Theriogenology, 79:760765.

Puangdee S, Duangjinda M, Boonkum W, Katawatin S, Buaban S, Thepparat M. 2017. Genetic associations between milk fat-to-protein ratio, milk production and fertility in the first two lactations of Thai Holsteins dairy cattle. Anim Sci J, 88:723-730.

Roche JF. 2006. The effect of nutritional management of the dairy cow on reproductive efficiency. Anim Reprod Sci, 96:282-296

Ruegg PL, Milton RL. 1995. Body condition scores of Holstein cows on Prince Edward Island, Canada: relationships with yield, reproductive performance, and disease. J Dairy Sci, 78:552-564.

Sangsritavong S, Combs DK, Sartori R, Armentano LE, Wiltbank MC. 2002. High feed intake increases blood flow and metabolism of progesterone and estradiol-17 $\beta$ in dairy cattle. J Dairy Sci, 85:28312842.

Sakaguchi M. 2009. Differences between body condition scores and body weight changes in postpartum dairy cows in relation to parity and reproductive indices. Can Vet J, 50:649-656.

Sawa A, Bogucki M. 2011. Effect of housing system and milk yield on cow fertility. Arch Tierz, 54:249-256.

Stadnik L, Atasever S. 2015. Influence of some environmental factors on body condition score and somatic cell count in Czech Holstein cows. Indian $J$ Anim Res, 49:774-777.

Stadnik L, Bezdicek J, Makarevich A, Kubovicova 
E, Louda F, Fellnerova I, Hegedüsova Z, Holasek R. 2017. Ovarian activity and embriyo yield in relation to the postpartum period in superovulated dairy cows. Acta Vet Brno, 86:51-57.

Stadnik L, Duchacek J, Beran J, Tousova R, Ptacek M. 2015. Relationships between milk fatty acids composition in early lactation and subsequent reproductive performance in Czech Fleckvieh cows. Anim Reprod Sci, 155:75-79.

Stadnik L, Louda F, Jezkova A. 2002. The effect of selected factors at insemination on reproduction of Holstein cows. Czech J Anim Sci, 47:169-175.

Tanaka T., Arai M, Ohtani S, Uemura S, Kuroiwa T, Kim S, Kamomae H. 2008. Influence of parity on follicular dynamics and resumption of ovarian cycle in postpartum dairy cows. Anim Reprod Sci, 108:134-143.

Thatcher WW, Bilby TR, Bartolome JA, Silvestre F, Staples CR, Santos JEP. 2006. Strategies for improving fertility in the modern dairy cow. Theriogenology, 65:30-44.

Ulutas Z, Sezer M, 2009. Genetic study of milk production and reproduction traits of local born Simmental cattle in Turkey. $J$ Agric Fac of Gaziosmanpasa Univ, 26:53-59.

Vacek M, Stadnik L, Stipkova M. 2007. Relationships between the incidence of health disorders and the reproduction traits of Holstein cows in the Czech Republic. Czech J Anim Sci, 52:227-235.

Wathes DC, Taylor VJ, Cheng Z, Mann GE. 2003. Follicle growth, corpus luteum function and their effects on embryo development in postpartum dairy cows. Reprod Supll, 61:219-237.

Yániz J, López-Gatius F, Bech-Sàbat G, GarcíaIspierto I, Serrano B, Santolaria P. 2008. Relationships between milk production, ovarian function and fertility in high-producing dairy herds in north-eastern Spain. Reprod Domest Anim, 43:38-43.

Zulu VC, Sawamukai Y, Nakada K, Kida K, Moriyoshi M. 2002. Relationship among insulin-like growth factor-1, blood metabolites and postpartum ovarian function in dairy cows. $J$ Vet Med Sci, 64:879885. 